\title{
New Causes of Central Precocious Puberty: The Role of Genetic Factors
}

\author{
Delanie Bulcao Macedo Vinicius Nahime Brito Ana Claudia Latronico \\ Unidade de Endocrinologia do Desenvolvimento, Laboratório de Hormônios e Genética Molecular/LIM42, \\ Disciplina de Endocrinologia e Metabologia, Hospital das Clínicas, Faculdade de Medicina, Universidade de São Paulo, \\ São Paulo, Brasil
}

\section{Key Words}

Central precocious puberty - Genetics .

Gonadotropin-releasing hormone $\cdot$ Kisspeptin $\cdot$ MKRN3

\begin{abstract}
A pivotal event in the onset of puberty in humans is the reemergence of the pulsatile release of the gonadotropin-releasing hormone $(\mathrm{GnRH})$ from hypothalamic neurons. Pathways governing $\mathrm{GnRH}$ ontogeny and physiology have been discovered by studying animal models and humans with reproductive disorders. Recent human studies implicated the activation of kisspeptin and its cognate receptor (KISS1/ KISS1R) and the inactivation of MKRN3 in the premature reactivation of $\mathrm{GnRH}$ secretion, causing central precocious puberty (CPP). MKRN3, an imprinted gene located on the long arm of chromosome 15, encodes makorin ring finger protein 3 , which is involved in ubiquitination and cell signaling. The MKRN3 protein is derived only from RNA transcribed from the paternally inherited copy of the gene due to maternal imprinting. Currently, MKRN3 defects represent the most frequent known genetic cause of familial CPP. In this review, we explored the clinical, hormonal and genetic aspects of children with sporadic or familial CPP caused by mutations in the kisspeptin and MKRN3 systems, essential genetic factors for pubertal timing.

(c) 2014 S. Karger AG, Basel
\end{abstract}

(c) 2014 S. Karger AG, Basel

0028-3835/14/1001-0001\$39.50/0

\section{Introduction}

The onset of puberty is first detected as an increase in the amplitude and frequency of gonadotropin-releasing hormone $(\mathrm{GnRH})$ pulses after a quiescent period during childhood. The reemergence of pulsatile GnRH secretion leads to increases in the secretion of the gonadotropins and of the luteinizing hormone (LH) and follicle-stimulating hormone (FSH) by the anterior pituitary gland and to the consequent activation of the gonadal function [1].

Pubertal timing is influenced by complex interactions of genetic, nutritional, environmental and socioeconomic factors $[2,3]$. Compelling evidence supporting genetic effects on pubertal timing has mainly been provided by population-based studies [4]. The role of genetic factors is also illustrated by the strong correlation between age of menarche in mothers and daughters, among members of an ethnic group, and by a greater concordance of pubertal timing between monozygotic as compared to dizygotic twins [5-7]. In addition, the pubertal pattern may be influenced by familial trends, such that families with a member with precocious or delayed puberty have a higher probability of having another affected member [8].

Central precocious puberty (CPP), also known as gonadotropin-dependent precocious puberty, is clinically defined by the development of secondary sexual characteristics before the age of 8 years in girls and 9 years in

\section{KARGER}

E-Mail karger@karger.com

www.karger.com/nen
Ana Claudia Latronico

Disciplina de Endocrinologia e Metabologia, Hospital das Clínicas

Faculdade de Medicina, Universidade de São Paulo

Av. Dr. Enéas de Carvalho Aguiar, 255, $7^{\circ}$ andar, sala 7037

São Paulo 05403-900 (Brazil), E-Mail anacl@ usp.br 
boys [9]. It results from the premature reactivation of the hypothalamic-pituitary-gonadal axis with pubertal levels of gonadotropins and consequent gonadal stimulation $[10,11]$. Affected children have premature and progressive sexual development associated with an acceleration in linear growth and advancement in bone age. No hypothalamic tumors or lesions are detected in the great majority of CPP patients, suggesting a different underlying mechanism, such as genetic, epigenetic and/or environmental factors $[9,10]$.

It is noteworthy that $\mathrm{CPP}$ has a striking predominance in girls. The estimated incidence of CPP in American girls is 1:5,000 to 1:10,000 [9]. Among Danish girls, the prevalence of CPP was 1:500 based on national registries over a 9-year period [12]. Precocious puberty can result in short stature and psychological and behavioral disorders in untreated patients [10]. Accumulating evidence suggests an association between early timing of puberty and adverse health outcomes in later life [13]. Early age at menarche has been associated with increased risks of obesity, hypertension, type 2 diabetes, ischemic heart disease, stroke, cancer and cardiovascular mortality [14-17].

In this review, we explored the recent human genetic findings described in patients with CPP that have shed light on the mechanisms involved in premature $\mathrm{GnRH}$ secretion.

\section{Familial CPP}

Familial CPP is usually defined by the existence of more than 1 affected member either in the proband generation or in the pedigree [8]. A proportion of children presenting with precocious or early puberty may have a positive family history. In an elegant observational study of children with early puberty, de Vries et al. [8] described 43 (42 girls and 1 boy) out of 156 children with idiopathic CPP who met the criteria for familial CPP (27.5\%). Segregation analysis suggested an autosomal dominant inheritance pattern with incomplete sex-dependent penetrance. Among the children with a family history of early puberty, a parent was affected in $47.8 \%$ and a first-degree relative in $93.5 \%$ of cases. Interestingly, precocious puberty was inherited maternally in 21 families and paternally in 10 families. In only 4 families, precocious puberty was inherited both maternally and paternally. Comparison between the familial and sporadic cases revealed a significantly lower maternal age at menarche (mean: $11.47 \pm 1.96$ vs. $12.66 \pm 1.18$ years) and a more advanced puberty in the familial CPP group [8].

\section{Rare Gain-of-Function Mutations in KISS1 and KISS1R}

In the last decade, the kisspeptin system was revealed as a major gatekeeper of puberty onset $[18,19]$. Several recessive loss-of-function mutations in KISS1R, a G-protein-coupled receptor, previously known as GPR54, were described in patients with congenital isolated hypogonadotropic hypogonadism [20]. In 2008, the kisspeptin system was also implicated in the pathogenesis of CPP in humans. Teles et al. [21] identified the first heterozygous activating mutation in the KISS1R (p.Arg386Pro) in an adopted Brazilian girl with CPP. This patient had thelarche from birth that progressed at 7 years of age and was associated with accelerated growth velocity, advanced bone age ( 11 years) and borderline pubertal GnRH-stimulated LH peak levels. In vitro studies revealed that the p.Arg386Pro mutation in KISS1R led to prolonged activation of intracellular signaling pathways in response to kisspeptin, resulting in a significant reduction in the desensitization rate [22]. Later, Silveira et al. [23] described a rare heterozygous missense mutation in KISS1 (p. Pro74Ser) in a boy with very early idiopathic CPP (1 year of age). He had very high basal LH and testosterone levels in the absence of brain lesions or tumors. His mother and maternal grandmother, who had normal pubertal development, also carried the p.Pro74Ser mutation in the heterozygous state, suggesting incomplete sex-dependent penetrance. The p.Pro74Ser mutation showed significantly greater capacity to stimulate signal transduction compared to the wild type after incubation with human serum in vitro, reproducing in vivo potential conditions. These findings suggested that the KISS1 variant might be more resistant to degradation, leading to greater kisspeptin bioavailability [23]. Although these case reports expanded the genotype-phenotype correlations for the kisspeptin pathways, no other CPP cases with gain-offunction mutations in KISS1R or KISS1 have been reported, suggesting that these genetic abnormalities are very rare. Other candidate genes implicated in the regulatory mechanism of $\mathrm{GnRH}$ secretion have also been screened (GABRA1, NPY-Y1R, LIN28B, TAC3, TACR3, TTF1 and $E A P 1)$, but no pathogenic variants were identified until recently [24-28].

\section{Loss-of-Function Mutations in MKRN3}

In 2013, applying whole exome sequencing, Abreu et al. [29] were able to identify 4 loss-of-function mutations in a single gene, $M K R N 3$, in 5 out of 15 families (33\%) 
Table 1. MKRN3 mutations described in children with typical clinical and hormonal CPP

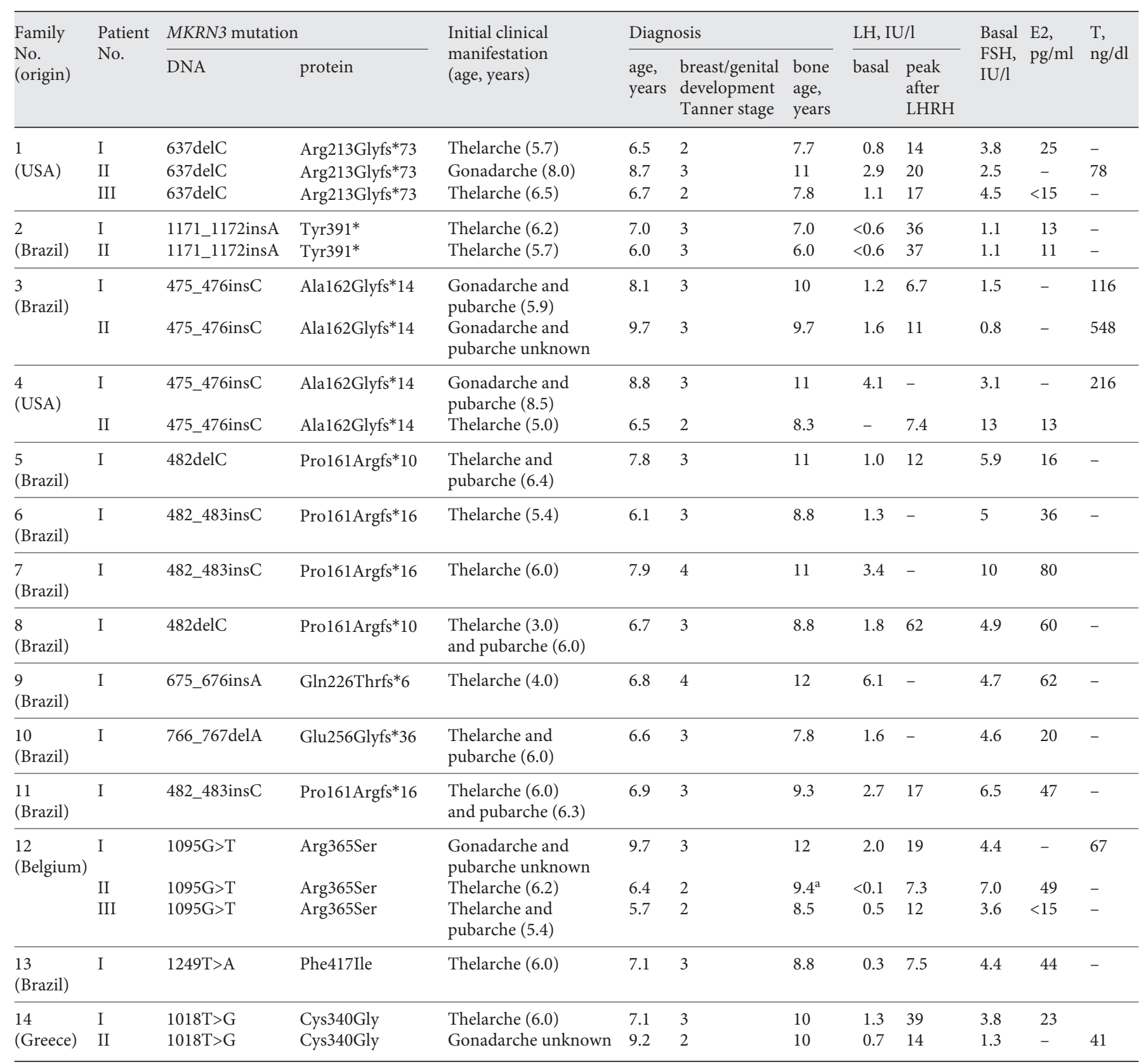

Gonadarche or testicular enlargement, breast/genital development Tanner stage and bone age assessed at the time of diagnosis [29, 31, 32]. E2 = Estradiol; $\mathrm{T}=$ testosterone.

${ }^{\text {a }}$ Bone age at 7.4 years.

with CPP. From a total of 40 members studied, 15 patients from both sexes ( 8 girls and 7 boys) with CPP carried $M K R N 3$ mutations. MKRN3 is an imprinted gene located on the long arm of chromosome 15q11.2 in the PraderWilli syndrome critical region and encodes the makorin ring finger protein 3 . The 5 affected families were origi- nated from North America, Brazil and Belgium, indicating that the MKRN3 mutations in patients with $\mathrm{CPP}$ were not restricted to a specific ethnic group (table 1). Their genotypes included $3 M K R N 3$ frameshift mutations predicted to encode truncated proteins and 1 missense mutation (p.Arg365Ser) predicted to disrupt protein function. 
Fig. 1. Schematic illustration of MKRN3 domains and the mutations identified in patients with CPP. The protein has 5 zinc finger domains: $3 \mathrm{C} 3 \mathrm{H}$ motifs, $1 \mathrm{C} 3 \mathrm{HC} 4$ RING motif with presumed ubiquitin ligase activity and $1 \mathrm{MKRN}$-specific Cys-His domain (green square). The numbers correspond to the amino acid positions in the protein. Frameshift mutations are shown in red, the nonsense mutation in black and the 3 missense mutations in green.

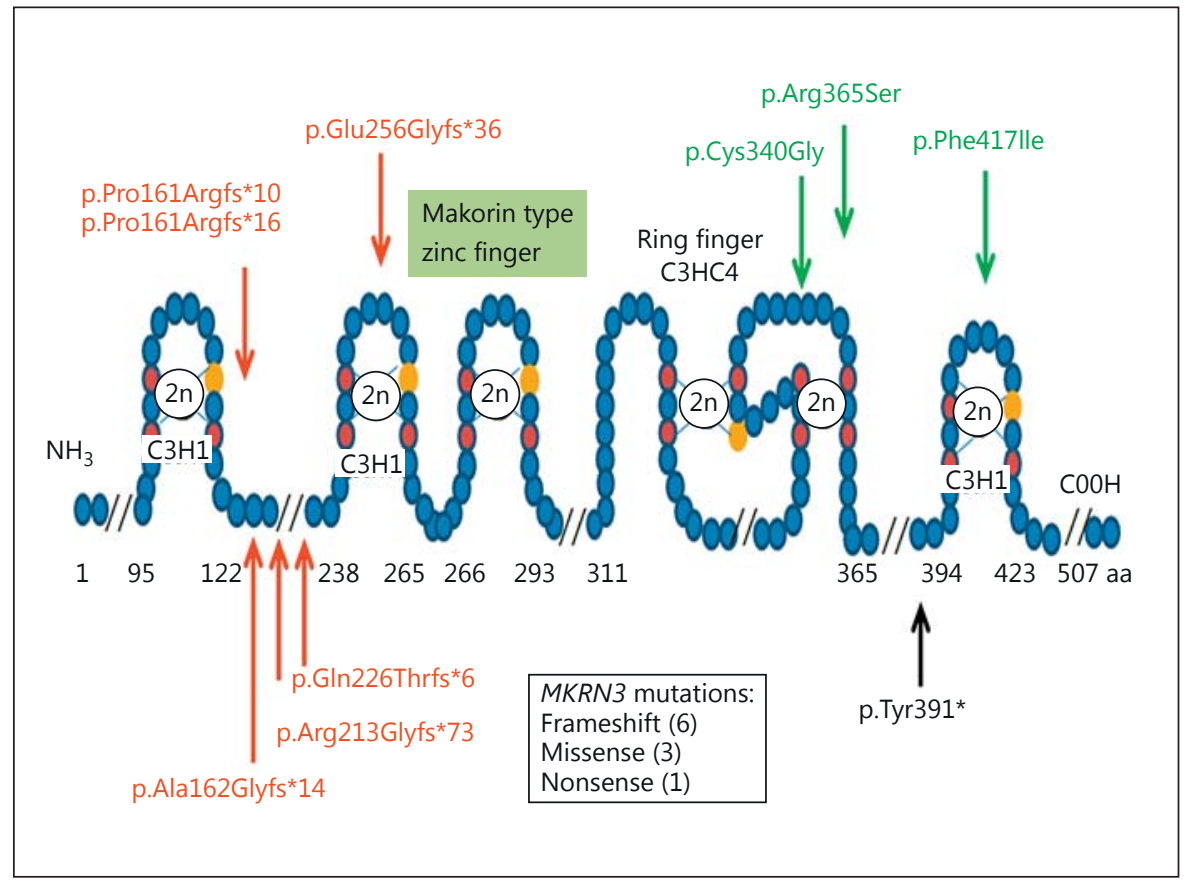

All affected individuals inherited their MKRN3 mutations from their fathers, demonstrating a perfect segregation with the mode of inheritance expected for a maternal imprinted gene.

Later, Settas et al. [30] reported a novel heterozygous MKRN3 mutation (p.Cys340Gly) in 2 Greek siblings, 1 girl with CPP and 1 boy with early puberty, further expanding the MKRN3 mutational spectrum. In accordance with the maternal imprinted pattern of $M K R N 3$, these 2 patients with CPP also received the mutated gene from their asymptomatic father. The p.Cys340Gly mutation was located in the C3HC4 RING motif of MKRN3 and it was predicted to disrupt the protein function in distinct in silico prediction programs.

More recently, Macedo et al. [31] analyzed 215 unrelated children (207 girls and 8 boys) with idiopathic CPP from 3 different university medical centers. No family history of premature sexual development was reported in the great majority of these patients ( 213 cases). Automatic sequencing of MKRN3 in this sporadic CPP cohort revealed 5 novel heterozygous mutations in 8 unrelated girls, including 4 frameshift variants and 1 missense variant (p. Phe417Ile). Segregation analysis demonstrated that the mutant allele was paternally inherited in all studied families. This finding confirmed a previous suspicion that the familial nature of CPP is frequently underrecognized [31]. Indeed, most children with CPP present for medical con- sultation accompanied by their mothers, and their paternal family history is often unknown or unavailable. Another limitation to the detection of familial CPP cases is to determine the precise onset of puberty in boys and in their fathers, since testicular enlargement is not as obvious as breast development and menarche in girls [32].

Currently, 10 different loss-of-function mutations of MKRN3 have been described in 22 patients with CPP from 14 multiplex families, including 6 frameshift defects, 3 missense mutations and 1 nonsense mutation (table 1). Interestingly, the frameshift mutations were largely located in the amino-terminal region of the protein which is codified by a rich poly $\mathrm{C}$ site, suggesting that this area can be a potential hot spot (fig. 1). These recent findings indicated that MKRN3 loss-of-function mutations are a cause of familial CPP in humans, establishing a clear and strong genetic component of this reproductive condition.

\section{Clinical Phenotype of Patients with MKRN3 Mutations}

Patients with CPP due to MKRN3 mutations had typical clinical and hormonal features of premature activation of the reproductive axis, including early pubertal signs, such as breast, testis and pubic hair development, accelerated linear growth, advanced bone age and elevat- 
ed basal and/or GnRH-stimulated LH levels. Only 3 patients ( 2 girls and 1 boy) with loss-of-function mutations in MKRN3 had mild nonspecific syndromic features, including 2 related patients with esotropia and 1 girl with high-arched palate, dental abnormalities, clinodactyly and hyperlordosis $[29,31]$. Notably, no major signs of Prader-Willi syndrome were detected in any patient with CPP caused by MKRN3 defects.

The age of pubertal onset in girls with CPP due to MKRN3 mutations ranged from 3.0 to 6.5 years (mean: 5.9 years; median: 6.0 years) [29-31], whereas in boys the age of pubertal onset or at diagnosis ranged from 5.9 to 9.7 years (mean: 8.5 ; median: 8.8 years) $[29,30]$. There is no explanation for the variation in the timing of precocity in patients with CPP due to MKRN3 mutations. Notably, no correlation was identified among patients who carried truncating mutations in comparison with those with missense mutations, suggesting that this age variability is not caused by the severity of the MKRN3 identified defects.

The mean ages of pubertal onset of patients with MKRN3 defects are in contrast with those reported in the 2 patients with gain-of-function mutations involving the kisspeptin system, who started pubertal development in the 1st year of life $[21,23]$. It must be noted that MKRN3 alterations seem to affect girls more severely than boys, since the mean age of pubertal onset was more anticipated in girls than in boys [30]. Therefore, gender dimorphism, which characterizes the physiological pubertal process, is also manifested in the MKRN3 affected cases.

No significant difference was observed in the median age of pubertal onset between patients with and without $M K R N 3$ mutations [31]. Given the median age (6 years) of pubertal onset of affected girls with MKRN3 mutations, it was speculated that the prepubertal inhibitory tonus on $\mathrm{GnRH}$ secretion apparently took place normally, but it was lost prematurely in patients with MKRN3 mutations. This clinical observation suggests that MKRN3 may not be crucial for GnRH suppression after the mini-puberty of early infancy, but that its downregulation plays a relevant role for the reemergence of $\mathrm{GnRH}$ pulses in the pubertal onset [31].

Simultaneous development of breast and pubic hair, as the initial clinical manifestations, was observed in $50 \%$ of the patients with CPP due to MKRN3 loss-of-function mutations [31]. Advanced bone age was found in all cases [29-31]. Median basal and GnRH-stimulated LH levels were $1.3 \mathrm{U} / \mathrm{l}$ (ranging from 0.1 to $6.1 \mathrm{U} / \mathrm{l}$ ) and $14 \mathrm{U} / \mathrm{l}$ (ranging from 6.7 to $62.5 \mathrm{U} / \mathrm{l})$, respectively [29-31]. Interestingly, significantly higher basal FSH levels in patients with MKRN3 mutations (median: $4.9 \mathrm{U} / \mathrm{l}$, ranging from 4.4 to
$10 \mathrm{U} / \mathrm{l})$ compared to those without MKRN3 mutations (median: $3.6 \mathrm{U} / \mathrm{l}$, ranging from 1.0 to $9.8 \mathrm{U} / \mathrm{l}$ ) were demonstrated in one study [31]. No definitive explanation for this difference was provided so far. If MKRN3 could play distinct roles in the release of the 2 pituitary gonadotropins, LH and FSH, remains unknown. The possibility of divergent neuroendocrine phenotypes was previously noted in patients with nonsyndromic hypogonadotropic hypogonadism caused by TAC3/TACR3 mutations. Pulsatile $\mathrm{GnRH}$ administration increased the $\alpha$-subunit pulsatile frequency and reduced the $\mathrm{FSH} / \mathrm{LH}$ ratio in these hypogonadic cases [33]. This gonadotropin axis dysfunction was related to low GnRH pulsatile frequency [33].

It is well known that depot $\mathrm{GnRH}$ agonists are the firstline treatment in progressive CPP [10]. Adequate clinical and hormonal control was reported in 6 of 8 patients with CPP due to MKRN3 mutations chronically treated with depot GnRH agonists [31]. Menarche occurred at an appropriate age in patients with continued follow-up. In addition, the predicted genetic final height was reached in the few reported patients with CPP due to MKRN3 who were adequately treated with GnRH analogs [31]. The long-term follow-up of patients with MKRN3 defects will certainly be very interesting to establish their risk of metabolic disorders and estrogen-dependent tumor development during later life.

\section{MKRN3 Expression and Protein Organization}

Human MKRN3 is an intronless gene located on chromosome 15q11.2. The maternal allele of this gene is silenced and only the paternal allele is expressed (monoallelic expression). The maternal methylation is established promptly after fertilization. Interestingly, MKRN3 can be reactivated in male gametogenesis for the next generation. Therefore, MKRN3 is a classic example of a methylated (inactivated) gene in female gametogenesis and of an unmethylated gene in male gametogenesis, being transmitted as an active gene in the sperm [34]. Hershko et al. [35], as part of an effort to generate a mouse model for the Prader-Willi and Angelman syndromes, demonstrated that the murine $m k r n 3$ gene (or $Z f p 127$ ) is also differentially methylated on the maternal allele. Jong et al. [36] showed that Zpf127 is expressed in the brain, heart and kidney of mice.

The precise mechanism by which MKRN3 deficiency leads to an early reactivation of pulsatile GnRH secretion remains to be elucidated. Abreu et al. [29] demonstrated higher Mkrn3 mRNA levels in the arcuate nucleus of male and female mice at young ages, with a prominent reduc- 
tion immediately before puberty, suggesting that the $M k r n 3$ mRNA expression pattern correlates with an inhibitory input in puberty initiation in these animals.

Proteins of the MAKORIN family have a highly distinctive zinc finger motif composition with 2 or 3 copies of a $\mathrm{C} 3 \mathrm{H}$ motif in the $\mathrm{N}$-terminal portion of the protein followed by a novel Cys-His configuration, a $\mathrm{C} 3 \mathrm{HC} 4$ RING zinc finger and a final $\mathrm{C} 3 \mathrm{H}$ motif [37]. $\mathrm{C} 3 \mathrm{H}$ zinc finger motifs have been implicated in RNA binding, while the RING zinc finger motif is found in most E3 ubiquitin ligases and is responsible for the ubiquitin ligase activity [38]. The widespread species conservation of the MAKORIN protein family points to vital cellular roles, with abundant expression in the developing brain, including the arcuate nucleus, where there is a group of genes whose expression is relevant to puberty [39]. Ubiquitination can also be a signal for transduction, cell cycle regulation, differentiation and morphogenesis, and other nonproteolytic fates [29].

The dramatic reduction in MKRN3 expression at the onset of puberty in mice in conjunction with the identification of loss-of-function mutations in humans with CPP suggested that MKRN3 might control puberty by potentially repressing downstream targets instead of activating the GnRH neuronal network [40]. Interestingly, MKRN3 is a member of the zinc finger family that can play a role as a transcriptional repressor of the human pubertal process. Indeed, this inhibitory mechanism appears to be a core component of the neuroendocrine circuitry that regulates the timing of puberty in primates [41].

Recently, the structural alignment of the native and mutant MKRN3 models predicted that the MKRN3 variant (p.Cys340Gly), identified in a Greek family with CPP, leads to significant structural perturbations in the 3-dimensional structure of the C3HC4 RING motif, supporting the functional implications of this MKRN3 missense mutation [30].

\section{Potential Imprinting Defects in CPP}

The Prader-Willi syndrome is a human imprinting disorder resulting from the disturbance of imprintedgene expression within human chromosome 15 [42]. This genetic condition appears to be a contiguous gene syndrome caused by the loss of at least 2 of a number of genes expressed exclusively from the paternal allele, including MKRN3, MAGEL2, NDN, SNRPN and several snoRNAs [42], but it is not yet known which specific genes in this region are associated with this syndrome. Deletion of chromosome 15q11-q13, which encompasses MKRN3, contributes to the Prader-Willi syndrome. Analyses of patients with the Prader-Willi syndrome and balanced translocations have implicated the SNURF-SNRPNlocus, telomeric to MKRN3 [43]. Particularly, a girl with a paternal deletion in MKRN3, MAGEL2 and NDN genes, who had few features of the Prader-Willi syndrome, had signs of puberty at the age of 7 years and 6 months with advanced bone age, leading to a diagnosis of CPP [43]. Considering that MKRN3 loss-of-function mutations cause CPP, the deletion of these genes is likely the underlying mechanism of the early puberty in this patient.

Interestingly, genes located on the long arm of chromosome 15 have been involved in human pubertal development based on clinical and genetic studies. It is well known that patients with the Prader-Willi syndrome typically have incomplete sexual development but, paradoxically, some begin to exhibit signs of puberty much earlier than expected [44]. Few cases of children with the Prader-Willi syndrome and precocious puberty have been reported [44]. Recently, it was investigated if CPP could arise from loss of MKRN3 expression by the paternal allele due to a de novo deletion, maternal uniparental disomy or an imprinting defect, mechanisms recognized in the pathogenesis of the Prader-Willi syndrome [31]. Using methylation-specific multiplex ligation-dependent probe amplification of chromosome 15q11, Macedo et al. [31] detected no abnormalities in the MKRN3 copy number as well as in the methylation pattern of the 15q11 locus in 52 patients with familial and sporadic CPP and normal MKRN3 sequence, suggesting that epigenetic defects in this chromosome region are probably rare mechanisms in this disorder.

Distinct chromosomal abnormalities have been associated with complex syndromic phenotypes, including CPP, such as 1p36 deletion [45], 1q11.23 microdeletion (Williams-Beuren syndrome) [46], 9p deletion [47], and maternal uniparental disomy of chromosomes 7 (SilverRussell syndrome) and 14 (Temple syndrome) [34, 48]. Interestingly, chromosome 7 and 14 maternal uniparental disomies are genomic imprinting disorders like the Prader-Willi syndrome. It is unknown if the impairment of one single gene located in these affected chromosome regions could explain the premature sexual development phenotype of syndromic patients, similarly to the recent description of MKRN3 on chromosome 15 [43]. Potentially, human genomic sequence and global methylation analyses in patients with familial or sporadic CPP could establish new genetic and epigenetic alterations in the pathogenesis of this reproductive pediatric disorder. 


\section{Conclusions and Perspectives}

The study of unique natural prototypes and deviations has helped disentangle and understand complex physiological processes. The study of patients with idiopathic familial CPP recently uncovered the role of MKRN3 in puberty initiation. Currently, MKRN3 defects represent the most frequent known genetic causes of familial CPP, and their analysis may provide an additional tool for the diagnosis of familial CPP cases. How MKRN3, an example of a neurobiological brake, interacts with other major players of puberty, such as kisspeptin, GnRH, leptin, neurokinin and a host of neurotransmitters (excitatory and inhibitory) will certainly continue to captivate scientists interested in the reproductive axis [39].

\section{References}

1 Terasawa E, Fernandez DL: Neurobiological mechanisms of the onset of puberty in primates. Endocr Rev 2001;22:111-151.

2 Gajdos ZK, Hirschhorn JN, Palmert MR: What controls the timing of puberty? An update on progress from genetic investigation. Curr Opin Endocrinol Diabetes Obes 2009; 16:16-24.

3 Palmert MR, Boepple PA: Variation in the timing of puberty: clinical spectrum and genetic investigation. J Clin Endocrinol Metab 2001;86:2364-2368.

4 Palmert MR, Hirschhorn JN: Genetic approaches to stature, pubertal timing, and other complex traits. Mol Genet Metab 2003;80: 1-10.

5 Fischbein S: Intra-pair similarity in physical growth of monozygotic and of dizygotic twins during puberty. Ann Hum Biol 1977;4:417430.

6 Parent AS, Teilmann G, Juul A, Skakkebaek NE, Toppari J, Bourguignon JP: The timing of normal puberty and the age limits of sexual precocity: variations around the world, secular trends, and changes after migration. Endocr Rev 2003;24:668-693.

7 Sklad M: The rate of growth and maturing of twins. Acta Genet Med Gemellol (Roma) 1977;26:221-237.

8 de Vries L, Kauschansky A, Shohat M, Phillip M: Familial central precocious puberty suggests autosomal dominant inheritance. J Clin Endocrinol Metab 2004;89:1794-1800.

9 Partsch CJ, Heger S, Sippell WG: Management and outcome of central precocious puberty. Clin Endocrinol 2002;56:129-148.

10 Carel JC, Léger J: Precocious puberty. N Engl J Med 2008;358:2366-2377.

11 Grumbach MM: The neuroendocrinology of human puberty revisited. Horm Res 2002;57: 2-14.

12 Teilmann G, Pedersen CB, Jensen TK, Skakkeback NE, Juul A: Prevalence and incidence of precocious pubertal development in Denmark: an epidemiologic study based on national registries. Pediatrics 2005;116:13231328.

13 Widén E, Silventoinen K, Sovio U, Ripatti S, Cousminer DL, Hartikainen AL, Laitinen J, Pouta A, Kaprio J, Järvelin MR, Peltonen L,
Palotie A: Pubertal timing and growth influences cardiometabolic risk factors in adult males and females. Diabetes Care 2012;35: 850-857.

14 Lakshman R, Forouhi N, Luben R, Bingham SA, Khaw K, Wareham N, Ong KK: Association between age at menarche and risk of diabetes in adults: results from the EPIC-Norfolk cohort study. Diabetologia 2008;51:781-786.

15 Lakshman R, Forouhi N, Sharp SJ, Luben R, Bingham SA, Khaw KT, Wareham NJ, Ong KK: Early age at menarche associated with cardiovascular disease and mortality. J Clin Endocrinol Metab 2009;94:4953-4960.

16 He C, Zhang C, Hunter DJ, Hankinson SE, Buck Louis GM, Hediger ML, Hu FB: Age at menarche and risk of type 2 diabetes: results from two large prospective cohorts. Am J Epidemiol 2009;171:334-344.

-17 Elks CE, Perry J, Sulem P, et al: Thirty new loci for age at menarche identified by a meta-analysis of genome-wide association studies. Nat Genet 2010;42:1077-1085.

18 Seminara SB, Messager S, Chatzidaki EE, Thresher RR, Acierno JS Jr, Shagoury JK, BoAbbas Y, Kuohung W, Schwinof KM, Hendrick AG, Zahn D, Dixon J, Kaiser UB, Slaugenhaupt SA, Gusella JF, O’Rahilly S, Carlton MB, Crowley WF Jr, Aparicio SA, Colledge $\mathrm{WH}$ : The GPR54 gene as a regulator of puberty. N Engl J Med 2003;349:1614-1627.

19 de Roux N, Genin E, Carel JC, Matsuda F, Chaussain JL, Milgrom E: Hypogonadotropic hypogonadism due to loss of function of the KiSS1-derived peptide receptor GPR54. Proc Natl Acad Sci USA 2003;100:10972-10976.

20 Seminara SB: Mechanisms of disease: the first kiss - a crucial role for kisspeptin- 1 and its receptor, G-protein-coupled receptor 54, in puberty and reproduction. Nat Clin Pract Endocrinol Metab 2006;2:328-334.

21 Teles MG, Bianco SD, Brito VN, Trarbach EB, Kuohung W, Xu S, Seminara SB, Mendonca BB, Kaiser UB, Latronico AC: A GPR54-activating mutation in a patient with central precocious puberty. N Engl J Med 2008;358:709-715.

22 Bianco SD, Vandepas L, Correa-Medina M, Gereben B, Mukherjee A, Kuohung W, Carroll R, Teles MG, Latronico AC, Kaiser UB: KISS1R intracellular trafficking and degradation: effect of the Arg386Pro disease-associated mutation. Endocrinology 2011;152:1616-1626.

-23 Silveira LG, Noel SD, Silveira-Neto AP, Abreu AP, Brito VN, Santos MG, Bianco SD, Kuohung W, Xu S, Gryngarten M, Escobar ME, Arnhold IJ, Mendonca BB, Kaiser UB, Latronico AC: Mutations of the KISS1 gene in disorders of puberty. J Clin Endocrinol Metab 2010;95:2276-2280.

24 Brito VN, Mendonca BB, Guilhoto LM, Freitas KC, Arnhold IJ, Latronico AC: Allelic variants of the gamma-aminobutyric acid-A receptor alpha1-subunit gene (GABRA1) are not associated with idiopathic gonadotropindependent precocious puberty in girls with and without electroencephalographic abnormalities. J Clin Endocrinol Metab 2006;91: 2432-2436.

25 Freitas KC, Ryan G, Brito VN, Tao YX, Costa EM, Mendonca BB, Segaloff D, Latronico AC: Molecular analysis of the neuropeptide Y1 receptor gene in human idiopathic gonadotropin-dependent precocious puberty and isolated hypogonadotropic hypogonadism. Fertil Steril 2007;87:627-634.

26 Silveira-Neto AP, Leal LF, Emerman AB, Henderson KD, Piskounova E, Henderson BE, Gregory RI, Silveira LF, Hirschhorn JN, Nguyen TT, Beneduzzi D, Tusset C, Reis AC, Brito VN, Mendonca BB, Palmert MR, Antonini SR, Latronico AC: Absence of functional LIN28B mutations in a large cohort of patients with idiopathic central precocious puberty. Horm Res Paediatr 2012;78:144150 .

27 Tusset C, Noel SD, Trarbach EB, Silveira LF, Jorge AA, Brito VN, Cukier P, Seminara SB, Mendonça BB, Kaiser UB, Latronico AC: Mutational analysis of TAC3 and TACR3 genes in patients with idiopathic central pubertal disorders. Arq Bras Endocrinol Metabol 2012;56:646-652.

28 Cukier P, Wright H, Rulfs T, Silveira LF, Teles MG, Mendonca BB, Arnhold IJ, Heger S, Latronico AC, Ojeda SR, Brito VN: Molecular and gene network analysis of thyroid transcription factor 1 (TTF1) and enhanced at puberty (EAP1) genes in patients with GnRHdependent pubertal disorders. Horm Res Paediatr 2013;80:257-266. 
29 Abreu AP, Dauber A, Macedo DB, Noel SD, Brito VN, Gill JC, Cukier P, Thompson IR, Navarro VM, Gagliardi PC, Rodrigues T, Kochi C, Longui CA, Beckers D, de Zegher F, Montenegro LR, Mendonca BB, Carroll RS, Hirschhorn JN, Latronico AC, Kaiser UB: Central precocious puberty caused by mutations in the imprinted gene MKRN3. N Engl J Med 2013;368:2467-2475.

30 Settas N, Dacou-Voutetakis C, Karantza M, Kanaka-Gantenbein C, Chrousos GP, Voutetakis A: Central precocious puberty in a girl and early puberty in her brother caused by a novel mutation in the MKRN3 gene. J Clin Endocrinol Metab 2014;99:E647-E651.

- 31 Macedo DB, Abreu AP, Reis AC, Montenegro LR, Dauber A, Beneduzzi D, Cukier P, Silveira LF, Teles MG, Carroll RS, Guerra Junior G, Guaragna Filho G, Gucev Z, Arnhold IJ, de Castro M, Moreira AC, Martinelli CE Jr, Hirschhorn JN, Mendonca BB, Brito VN, Antonini SR, Kaiser UB, Latronico AC: Central precocious puberty that appears to be sporadic caused by paternally inherited mutations in the imprinted gene makorin ring finger 3. J Clin Endocrinol Metab 2014;99:E1097-E1103.

32 Pigneur B, Trivin C, Brauner R: Idiopathic central precocious puberty in 28 boys. Med Sci Monit 2008;14:CR10-CR14.

33 Francou B, Bouligand J, Voican A, Amazit L, Trabado S, Fagart J, Meduri G, Brailly-Tabard S, Chanson P, Lecomte P, Guiochon-Mantel A, Young J: Normosmic congenital hypogonadotropic hypogonadism due to TAC3/ TACR3 mutations: characterization of neuroendocrine phenotypes and novel mutations. PLoS One 2011;6:e25614.
4 Butler MG: Genomic imprinting disorders in humans: a mini-review. J Assist Reprod Genet 2009;26:477-486.

35 Hershko A, Razin A, Shemer R: Imprinted methylation and its effect on expression of the mouse Zfp127 gene. Gene 1999;234:323-327.

36 Jong MT, Carey AH, Caldwell KA, Lau MH, Handel MA, Driscoll DJ, Stewart CL, Rinchik EM, Nicholls RD: Imprinting of a RING zincfinger encoding gene in the mouse chromosome region homologous to the Prader-Willi syndrome genetic region. Hum Mol Genet 1999;8:795-803.

37 Gray TA, Hernandez L, Carey AH, Schaldach MA, Smithwick MJ, Rus K, Marshall Graves JA, Stewart CL, Nicholls RD: The ancient source of a distinct gene family encoding proteins featuring $\mathrm{RING}$ and $\mathrm{C}(3) \mathrm{H}$ zinc-finger motifs with abundant expression in developing brain and nervous system. Genomics 2000;66:76-86.

38 Böhne A, Darras A, D’Cotta H, Baroiller JF, Galiana-Arnoux D, Volff JN: The vertebrate makorin ubiquitin ligase gene family has been shaped by large-scale duplication and retroposition from an ancestral gonad-specific, maternal-effect gene. BMC Genomics 2010; 11:721.

39 Hughes IA: Releasing the brake on puberty. N Engl J Med 2013;368:2513-2515.

40 Ojeda SR, Lomniczi A: Puberty in 2013: unravelling the mystery of puberty. Nat Rev Endocrinol 2014;10:67-69.

41 Lomniczi A, Loche A, Castellano JM, Ronnekleiv OK, Bosch M, Kaidar G, Knoll JG, Wright H, Pfeifer GP, Ojeda SR: Epigenetic control of female puberty. Nat Neurosci 2013; 16:281-289.
42 Peery EG, Elmore MD, Resnick JL, Brannan CI, Johnstone KA: A targeted deletion upstream of Snrpn does not result in an imprinting defect. Mamm Genome 2007;18:255-262.

43 Kanber D, Giltay J, Wieczorek D, Zogel C, Hochstenbach R, Caliebe A, Kuechler A, Horsthemke B, Buiting K: A paternal deletion of MKRN3, MAGEL2 and NDN does not result in Prader-Willi syndrome. Eur J Hum Genet 2009;17:582-590.

44 Lee HS, Hwang J: Central precocious puberty in a girl with Prader-Willi syndrome. J Pediatr Endocrinol Metab 2013;30:1-4.

45 Kurosawa K, Kawame H, Okamoto N, Ochiai Y, Akatsuka A, Kobayashi M, Shimohira M, Mizuno S, Wada K, Fukushima Y, Kawawaki $\mathrm{H}$, Yamamoto T, Masuno M, Imaizumi K, Kuroki Y: Epilepsy and neurological findings in 11 individuals with 1p36 deletion syndrome. Brain Dev 2005;27:378-382.

46 Partsch CJ, Japing I, Siebert R, Gosch A, Wessel A, Sippell WG, Pankau R: Central precocious puberty in girls with Williams syndrome. J Pediatr 2002;141:441-444.

47 Cisternino M, Della Mina E, Losa L, Madè A, Rossetti G, Bassi LA, Pieri G, Bayindir B, Messa J, Zuffardi O, Ciccone R: Idiopathic central precocious puberty associated with $11 \mathrm{mb}$ de novo distal deletion of the chromosome 9 short arm. Case Rep Genet 2013;2013: 978087.

48 Grosso S, Anichini C, Berardi R, Balestri P, Pucci L, Morgese G: Central precocious puberty and abnormal chromosomal patterns. Endocr Pathol 2000;11:69-75. 